\title{
Et ansigt som minder om norsk poesi
}

Sønderho, søndag, den 10. august 2008

Kære Geir,

Noget der har murret i mig et stykke tid; at der midt i den nye spændende norske poesi findes et stadig stærkere religiøst, måske kristent spor. Jeg tænker på Steinar Opstad, Gunnar Wærness og Monica Aasprong. Særligt de sidste to er jo nyskabende, jeg ved ikke om man i Norge kalder dem for eksperimenterende, den label ville de nok få på sig i Danmark, selvom det her som regel har negative konnotationer, det står som en slags advarsel: ADVARSEL! DENNE DIGTER ER EKSPERIMENTERNDE! Men det er et sidespor. Wærness og Aasprong, jeg tænkte det da jeg læste deres seneste bøger - Soldatmarkedet i sine mange versioneringer (fx 2007), og Hverandres (2006) og Bli verden (2007) - at man iblandt den særlige interesse for de visuelle, taktile, materielle kvaliteter, det situerede, spillet i det, også kan tyde et religiøst spor. Aasprong har sagt at hun igennem sit arbejde med Soldatmarkedet er blevet opmærksom på at t'et bærer korset i sig. I det perspektiv bliver hendes næsten uendelige landskabsagtige t-permutationer pludselig ligesom... oplyst nedefra... Hvor udskillelsen af fonemet, tænker jeg, umiddelbart kunne handle om en art reduktion af det sproglige udtryk, en undersøgelse af netop mere materielle aspekter af de tegn der til daglig og i deres vanlige sammenhænge er usynlige for os, bliver de pludselig til kors. Altså opladet med en massiv symbolsk og historisk betydning. De bliver tømt for deres t-hed, så at sige, og fyldt med KORS. De opererer jo ikke løsrevet i Aasprongs digte, men indgår i et bølgende tæppe, en mark, hvor de, i skriftens ophold, danner forskellige figurationer, skaber forgrund og baggrund på siden, dybde. Bogsiden bliver altså rumliggjort på en anden måde i disse arbejder end man er vant til at se det i mere konventionel litteratur, selvom en stor del af poesien selvfølgelig altid grundlæggende har arbejdet visuelt betydende, $\mathrm{fx}$ i linjeskiftets talende tavshed, hvis ikke det lyder for 
corny. Jeg er interesseret: Hvad tænker du om Monica Aasprongs Soldatmarkedet? Indgangsdigtet i Gunnar Wærness Hverandres, 'Kjære bønn', er, som titlen vel mere end antyder, et digt, en bøn, rettet til bønnen, en metabøn på sin vis: "Kjære bønn jeg ber deg - måtte det komme / ikke bare ord og bilder - men et menneske / gjennom dine ord - et menneske som finnes / som kaller meg - og finner meg"; de sakrale topoi forekommer mig at være gennemgående for en del af den markante nyere norske poesi. Og det i modsætning til den danske samtidspoesi. Selvom den hollandske lektor Henk van den Liet for nylig i Danish Literary Magazine skrev om "the growing significance of religion" i dansk samtidspoesi, må jeg sige at jeg ikke synes det er oplagt. Hvis man ser bort fra Simon Grotrian. Opstad er en meget anderledes poet end de to andre, mere traditionel, og dog: Der er visse affiniteter imellem ham og Wærness, er der ikke? Forkynderiet, alvoren, pausernes buldren, det enkelte ords vægt? I dansk sammenhæng ville han være i familie med Ole Sarvig, Søren Ulrik Thomsen og samtidig, altid, nogle andre, noget andet, sig selv, men mistroen til sproget, til ordene man bruger, om de kan bruges til noget, den deler han i sit arbejde, så vidt jeg kan se, med både Monica Aasprong, Gunnar Wærness og dig selv. Denne længsel, som man også kan se i Wærness-citatet ovenfor, og meget stærkt i din egen seneste bog - og i grunden igennem hele dit lyriske forfatterskab - efter at ordene skal betyde noget, at de skal blive virkelige, at ordet skal blive kød: Måtte der komme ikke bare ord ud af dette, men et rigtigt levende menneske, en anden. I din bog pågår der en ret aggressiv virkelighedsdiskussion, sådan opfatter jeg det: aggressivt, næsten som et indlæg i en samtidig norsk litterær debat - er det det? Du forsøger i din skrift at gøre opmærksom på at det er en falsk dikotomi - skrift vs virkelighed - jamen, det gør vi alle, dén diskussion har man igen og igen, men er den særlig presserende i Norge? Jeg opfatter den som nærværende i jeres tekster. Og måske som et problem for digterne selv - som om I selv er dybt i tvivl. Alt det kom jeg til at tænke på (igen), da jeg i aftes læste manuskriptet til din nye digtsamling et ansikt som minner / om norsk politikk (2008); en meget, skal vi sige anti-metafysisk digtsamling, der simpelthen ender med at den afdøde bror der bogen igennem forsøges forstået, afbilledet, erindret optræder som engel ("og da jeg ser ut av vinduet har broren min for lengst blitt borte / han har løftet de svarte sjaskete vingene sine og flydd"); det var en meget overraskende slutning for mig. Hvad tænker du selv om denne vel metafysiske udgang, hvis den er det, hvis ikke den er symbolsk eller tung metaforisk eller hvad man skal kalde det, hvad tænker du om et markant religiøst spor i den nyere norske digtning, hvordan, fra dit perspektiv, ser et ansigt der minder om norsk poesi mon ud?

på kjøkkenet hjemme, Oslo, tirsdag 12. august

Kjære Martin,

Den kvelden mailen din kom, lå jeg på ryggen på gulvet og leste Saramago. Her er en setning: "... alt dette er jordiske ting, som skal bli værende på jorden, og av dem er det den eneste mulige historie blir skapt." 
Først forsto jeg ikke hvorfor jeg ble så sint (vred!) da jeg leste brevet ditt. Jeg blir ofte sint, riktig nok, oftere og oftere, tror jeg, og dette sinnet minnet meg om noe jeg har hisset meg opp over før, og det er ikke så bra, for når jeg blir sint blir kroppen så urytmisk, jeg blir rykkete og ufri i bevegelsene, og det gjør tankene også, jeg blir sittende og hamre på tastaturet slik at jeg nesten ikke selv forstår etterpå hva jeg har prøvd å skrive, og så blir alt feil, for det eneste som egentlig interesserer meg er jo å prøve å bli fri, litt friere. Hvorfor skulle jeg ellers skrive dikt? Eller lese dikt?

Men der kommer du trekkende med ord som metafysikk og religion. Å, jeg er så trøtt av den typen fortolkningsfundamentalisme, dette stilige alvoret som skal anlegges hver gang vi snakker om litteratur, denne evinnelige diskusjonen av opphøyde temaer; o, ja, metafysikken vender tilbake eller fordrives, akkurat som metaforen fordrives eller vender tilbake, akkurat som en hvilken som helst litterær forretningsidé blir etablert og solgt og drevet tilbake igjen, satt opp som eneste mulighet og deretter stilt i miskreditt. Jeg er i mot disse litterære forretningsideene, akkurat som jeg er i mot kirkedannelser, alle, men særlig innenfor poesi, en av de få sjangrene hvor man i prinsippet skulle kunne skrive seg ut av formlene, ut av trangen til å oppdage det som har vært oppdaget før. Men her kommer altså du og oppdager religion og kristendom i noen nyere norske dikt. Hør på deg selv nå: at det finnes et stadig sterkere religiøst eller kristent spor i poesien som skrives? Kristendom, Martin??? Jeg hører allerede ekkoet fra kulturkommentatorene som skal levere de neste litteraturhistoriske blødmene om den nye kristne vendingen i norsk poesi. Jeg snur meg mot veggen og lukker øynene. Martin, hør på meg, vær så snill, for hvis dette var sant, ville det skrives flere og flere dikt som støtter seg på dogmer det ikke kan gjøres rede for innenfor diktet. Det gjør riktig nok alle dikt, selv vi som later som noe annet, men likevel, Martin, likevel! De troende stiller gode spørsmål, men nøyer seg med dårlige svar, forbløffende dårlige, slik er det jo. Og de poetene du nevner har nesten ikke noe annet felles enn at de har blitt lest av deg, akkurat nå. Å nei, herre gud, holdt jeg på å si, hold nå kjeft, Martin. Eller altså: si noe annet.

(Men hvis vi overhode skal skrive brev til hverandre må jeg jo ta det du sier alvorlig?) (Jeg må jo det.) (Og hvorfor skulle jeg ikke det?)

Mellom den forrige setningen og denne har jeg vært ute. Jeg gikk til sykehuset i enden av gata jeg bor i, jeg hadde time der for å gi blod. Hver gang jeg skal gi blod må jeg krysse av på et skjema der jeg skal forsikre Blodbanken om at jeg ikke er født i Amerika sør for USA, og at jeg ikke har vært utenfor Vest-Europa de siste seks måneder, ikke har fått akupunktur, ikke blitt bitt av flått, ikke mottatt penger eller narkotika som gjenytelse for sex, ikke stukket eller skåret meg på gjenstander som var forurenset med blod eller andre kroppsvæsker, og at jeg ikke har hatt seksualpartner som har vært i Afrika. I tillegg til en hel del annet - for eksempel at jeg ikke oppholdt meg i Storbritannia i mer enn ett år i perioden mellom 1980 og 1996. Det minner meg om at jeg en gang eide en mobiltelefon der det i bruksanvisningen ble advart mot å la telefonens software bli videreformidlet i en rekke navngitte land, som for eksempel Irak og Iran. Og nøyaktig slik ser det ut til å være når man forholder seg til dikt også: først må det krysses av for diktenes forhold til metaforer, metafysikk og materialisme, det må avklares hvilken litterær kirke diktene ønsker 
å slutte seg til, og så kan fortolkningen begynne. Diktenes software kan med andre ord kun anvendes i på forhånd godtatte sektorer.

Ja? Men når jeg prøver å lese det du har skrevet enda en gang, blir jeg sittende og se på følgende setning: "Forkynneriet, alvoret, pausenes buldring, det enkelte ords vekt." Det er en fin setning. Du snakker om likheter mellom Steinar Opstad og Gunnar Wærness. Men hvis du ser isolert på denne setningen, kunne den vel vært brukt om veldig mange andre poeter også, Martin? Alvoret hos den ene er helt annerledes enn alvoret hos den andre (humoren også). Pausene er vilt forskjellige. Med forkynneriet mener du vel noe som har med tonen i utsigelsen å gjøre, ikke at det forkynnes sannheter i den ene eller andre retning, men at det finnes en særegen klang i visse dikt som minner deg om noe kirkelig? Akkurat som alvoret, og den fantastiske buldringen du har hørt i pausene. Vel, Martin, ta en titt på dine egne dikt, eller et hvilket som helst dikt av en god poet du har lyst til å lese. Det ville overraske meg om ikke pausene buldrer der også, og om ikke alvoret blant annet er alvorlig, men på forskjellige måter for hver gang. Jeg ser rett og slett ingen annen likhet mellom disse to poetene enn at de i enkelte dikt har anvendt ord fra en religiøs motivkrets: bønn og bud og tavler. Men anslaget, tonen, måten å skrive på og hva de skriver om og hva de oppnår er jo helt forskjellig. NEI, det finnes ikke et kristent spor i nyere norsk poesi, Martin, her er jeg sikker på at du tar helt feil. Dette er ikke noe du finner i diktene, annet enn på et overflatisk plan, og da kunne du like gjerne funnet noe helt annet, og det er dette som gjør meg så sint så ofte, tror jeg, at vi alt for lett stempler inn et hvilket som helst utdatert sjekkpunkt så snart vi skal snakke om dikt. Hvorfor undersøker vi ikke heller hva det er som gjør at enkelte dikt etablerer en tone eller en diksjon eller en rytme eller et språkleie, en melodi, en måte å få språket til å synge eller mumle eller stamme på som er åpnende, ugardert, lyttende og uhørt og -ja, nå prater jeg i vei, og det ble ikke mye presisjon over dette, er jeg redd.

på kjøkkenet (som vanlig), onsdag 13. august

I dag morges satt jeg og leste i Eldrid Lundens diktsamling Til stades. Den er åtte år gammel, og sånn sett absolutt "nyere norsk poesi", nyere enn mye annet, forresten. Korte og lange dikt, reisedikt, refleksjonsdikt, lange prosapartier, korte impresjonistiske (kanskje) bilder, tekster om etruskerne og maurerne, om svaler, om en mor, om Botticelli, men først og fremst er det en pust, et tonefall, en melodi i måten å snakke på som virker fri, befridd, frigjørende. Det er nesten umulig å sitere fra disse diktene fordi de arbeider sammen, kontrastene og sprangene og hilsenene mellom tekstene er så viktige.

Men likevel: "Tåke i november. Nesten ingen sikt. Stubbemønsteret i kornåkeren utanfor / vindauga liknar på ei prikk eit nærbilde av hud vi såg på TV i går // Eit åkerland med vakre og heilt naturlege spor etter mekaniserte driftsmåtar."

Hva skjer her? Diktet ser ut av vinduet, det er november, stubbåkrene utenfor vinduet minner om et nærbilde av hud. Det er helt hverdagslig og konkret og raskt gjennomlyst av en tanke, en sammenligning. Språklig skal man for eksempel merke seg at noe i tonefallet gjør det mulig å bruke ord som "vakkert" og "naturlig", sånne 
ord som alle grunnkurs i diktskriving ville prøvd å sette på indeks, stryke, fordi vi tror de er tomme, forslitte. Men det såkalt naturlige vrir seg jo her til sin såkalte motsetning, der det som er naturlig også omfatter mekaniserte driftsmåter. Og når dette bildet smeller tilbake igjen i sammenligningen har du et bilde av hud, og dermed av kroppen, og dermed av menneskelighet som er litt større enn refleksene våre vil ha det til.

Og dermed er det viktig hva de ulike språkleiene brukes til, ikke sant? Innledningsvis i denne boka står det: "Svala har ingen kropp // Den stuper i vår erindring". Konkrete og abstrakte vendinger vrir seg om hverandre, slik ulike diskurser (jeg klarer faen ikke å unngå det ordet, jeg beklager) også vrir seg inn i hverandre. Og det er typisk at når Lunden skriver om etruskerne, er inngangen hennes D. H. Lawrences refleksjoner om dette folket. Altså: kanskje er det skjønnlitterære, poetiske blikket et eget system, en måte å skrive og tenke på som jobber ved siden av og inne i alle de andre måtene å skrive og tenke på?

Noe av det mest pinlige og spesielle i den norske litterære situasjonen akkurat nå er jo forsøkene på å gjøre sakprosaen til en ny nasjonallitteratur. Dette handler bare om politikk, eller altså økonomi, men det ideologiske arbeidet rundt dette prosjektet har ført med seg mye merkelig, det har blitt produsert enorme mengder kunstfiendtlig og innsnevret og demagogisk språk i den anledning. Det morsomme er likevel at da Dagbladet skulle kåre tidenes norske sakprosabok, var det Georg Johannesens Den norske tenkemåten (1975) som ble kåret. Kjartan Fløgstad karakteriserer Georg Johannesens artikler om politikk og litteratur og tenkning presist nok som artikkeldiktning; dermed ramlet store deler av sakprosaforkjemperne gjennom gulvet igjen og måtte bade i et større språk.

Du har jo sitert Johannesen selv i et av dine dikt: å leve er nødvendig men neppe nok. Og jeg husker at den linjen du siterte gikk nesten umerkelig inn i diktet, men likevel ikke. Det var fint å se hvordan den sto der og vendte seg. Men hva gjorde dette med diktet ditt? Det burde noen undersøke.

Er jeg virkelig nødt til å kommentere din kommentar til meg om en metafysisk utgang på Et ansikt som minner om norsk politikk? Må jeg det, som vi sier på norsk? Jeg må vel det. Hør på meg, Martin! Du skriver at den døde broren i denne boka helt til slutt opptrer som engel, men det gjør han ikke, det står at han viser seg som ei vanlig norsk skjære. Ei skjære er en fugl, også kalt pica pica, og på dansk har jeg nettopp funnet ut at den heter Husskade. Hvorfor det, tro? Det er en jævla bandittfugl, ikke sant, men en fugl likevel, og ganske smekker å se på. Her hvor jeg bor hadde vi et år en hel bande med skjærer som terroriserte alle naboene, hver gang jeg kom hjem pleide en av dem å seile ned over hodet på meg og skrike høyt, som om jeg ikke var velkommen, det vil si: det var jeg altså ikke, slik den skjæra så det, for den var jeg bare en inntrenger, og det samme var den selvfølgelig for meg. Forstår du, Martin? Du ville finne metafysikk i diktene du leste og derfor fant du det. Men skjærer er ikke engler. Og jeg tror at om du går tilbake til de andre poetene du siterte vil du kunne se at alle disse poetene anvender ulike språksjikt til helt ulike formål.

Men for å snakke om sånt må det nærlesning til, ja mer enn nærlesning, det som kreves er en mikrolesning, tror jeg faktisk, en helt konkret studie av pusten, rytmen, av melodien i det som blir skrevet og på hvilken måte denne melodien bærer mening 
og intelligens inn i et dikt. Det skjer nesten aldri. Jeg ender der, foreløpig, litt upresist og påståelig og pompøst. Men jeg fortsetter gjerne.

Sønderho, natten og morgenen mellem tirsdag og onsdag, den 18. og 19. august 2008

\section{Kære Geir,}

Da din mail kom læste jeg Henrik Stangerups roman Løgn over løgn. Det er en todelt roman, der dels består af et traditionelt fiktionsspor og dels af et metaspor der indirekte kommenterer fiktionssporet og meget direkte den samtid, som det vel er romanens sigte at analysere igennem dette dobbeltblik, disse to samtidige strategier. Bogen er fra 1971. Det lyder måske meget spændende, men er det ikke rigtigt, det starter godt og så, pludselig, går det nedad bakke med samme fart som en pil og med den stakkels læser som modvilligt vidne. Ihvertfald hvis man, som jeg, læser den færdig, måske gjorde jeg det mest af princip, mest af litteraturhistorisk interesse, men LYST er jo det der for alvor gør litteraturen (og meget andet) værd at beskæftige sig med. En af de væsentlige grunde til at Stangerups dobbeltroman i mine øjne kæntrer er, tror jeg, at der er et overvældende fokus på det man kunne kalde indhold, der er én idé der skal fyldes ud. Det trætter. Det bringer intet nyt, ikke for mig, jeg oplevede ikke noget særligt i bogens to sidste tredjedele, og jeg tror det i høj grad har at gøre med manglen på temperament i eller interesse for det du kalder rytmen, melodien, åndedrættet. Stilen genererer indholdet, intet er så dødsygt som at læse en bog der er udtænkt på forhånd og tilsyneladende er skrevet på samme måde som forfatteren ville løse en Soduko; alle felterne er der allerede, nu er det er bare at udfylde dem med de rigtige tal, så det hele går O-P = OP. Jeg er altså slet ikke uenig i at de små steder; stemmen, tonen, sætningernes hårdhed eller tyngde, måden pauserne fungerer produktivt på, bør vies uhyre opmærksomhed, at de kan fortælle os meget, hvis vi lytter. Alligevel er jeg lidt overrasket over din heftighed; det er næsten som du hævder at særlig én bestemt måde at tale om poesien på fjerner os fra de poetiske realiteter, fra skønheden, hvis du vil tillade mig at bruge det ord, det umiddelbare - som om ( $\mathrm{fx}$ den tematiske) tænkning af poesien ikke også skulle kunne være en del af den umiddelbare oplevelse? Selvom det jo ikke er fordi du er against interpretation i dit brev, du vil have grundigere nærlæsninger, mikrolæsninger, og JA, vi bør kvalificere vores læsninger, det gør vi ikke ordentligt her, underbygger vores påstande, går i detaljen, men i den mikroskopiske læsning, det må man ikke glemme, er der en masse (indlysende) ting man dårligt får øje på fordi med er for langt nede i detaljen, for tæt på. Personligt kan jeg ikke se hvordan nærlæsningen skulle udelukke en mere overordnet interesse, en (ugleset) tematisk læsning fx, jeg kan slet ikke se hvordan disse forskellige læsestrategier skulle være hinandens modsætninger, hvorfor de skulle være uforenelige?

Din vrede, hvad kan den mon skyldes, i hvert fald en modstand imod at læse TEMATISK, den modstand er jo kendt, det er ikke commes il faut, men er det ikke sandt at det tematiske niveau er én måde for en tekst at handle om noget på? Hvis jeg skal forsøge at definere hvad en tematisk læsning handler om, kan man sige 
at temaet er noget der via formen også samtidig er uafhængig af den i kraft af at det kan resumeres i en anden form. Det er netop igennem formen man varierer et tema. Det er temaer vi resumerer når vi forsøger at fortælle hvad en bog handler om på et mere overordnet plan og med andre ord. Menachem Brinker skriver i antologien Thematics (1995) om temaet, at det ikke kun er til stede i tekster, men også for eksempel i pantomimer, hvorfor temaet altså kan overleve endda helt uden ord. I samme antologi skriver Shlomith Rimmon-Kenan om hvordan den tematiske læsning anses for at være suspekt, blandt andet som følge af dekonstruktionens fremkomst. "Siden dekonstruktionen", skriver han, "er enhed [unity] faldet i miskredit"; men ifølge Rimmon-Kenans egen analyse af særligt den amerikanske dekonstruktion, tematiserer den meget ofte fravær af mening eller entydige, stabile betydningers umulighed. Det synes jeg var en interessant pointe da jeg første gang læste den. Nu har jeg været i bøgerne og finde den frem igen. Igennem dit eget forfatterskab ville man hurtigt finde den nære elskedes død som en genkommende topos eller tema (jeg tænker umiddelbart på Voksne dikt; Hannu, Hannu; Et ansikt som minner om norsk politik), problemet er bare at det ikke er særlig meget at sige om en tekst: at den handler om døden. At den blandt andet handler om døden. Man må kombinere det med andre læsestrategier hvis det skal give mening. Selv fremhæver du rytme osv. som en måde at betyde på, som en måde der er vigtigere end andre måder, lader det til. Den holdning deler jeg ikke - ligesom jeg heller ikke mener at den tematiske læsning bør have forrang frem for andre - den form for hierarkisering giver for mig ikke mening, det er én måde at tale om teksterne på der kan afdække visse aspekter, men man må kombinere det med andre måder for at få andre, mere nuancerede og interessante og gerne for mig også selvmodsigende svar.

Du skriver at jeg lige så vel kunne have fundet noget andet end dette overfladiske kristne spor (lad os bare kalde det det) i disse digte; det benægter jeg ikke, nærmest tværtimod, men skulle det være et problem? At der er flere ting til stede samtidig? Kun hvis man tror på en art poesiens monokausalitet - at der kun er én årsag til at et digt er et godt digt (at det opererer med en kristen tematik eller at det får sproget til at mumle for eksempel) og så radikale er der vel alligevel ingen der er? Overfladiske ligheder, jo... men de er der dog, disse overfladiske ligheder, skal vi kalde det et kristent vokabular, jeg ved ikke om det er karakteristisk for den yngre norske poesi, men hos unge, eksperimenterende danske digtere findes det ikke, vil jeg påstå, og hvordan kan det være? Hvad kan det betyde? Det er spørgsmål, kan jeg forstå, du finder komplet meningsløse?

Hvad er i øvrigt ikke en litterær forretningsidé? Hvordan synes du vi kan tale om den samtidige norske litteratur, synes du vi skal tale om den samtidige norske litteratur (det er jo ikke sikkert) og hvorfor (ikke)?

Den fugl til slut i dit digt, du har ret, det er nok ikke en engel, det var måske at gå for vidt i min læsning, men hvad er det så, spørger jeg jo om i mit brev? Så konkret og uformidlet og virkelighedsagtig er den vel ikke? Den optræder i et digt. Og du tænker vel næppe at læseren skal tro at jegets bror er en husskade? Nej, altså må det være noget andet med fuglen der gør at du vælger at portrættere ham sådan - du skriver selv i din mail om en masse karakteristika ved den fugl, måske det 
er det "jævla" banditagtige du vil have med? Som jeg læser bogens sidste digt (der i virkeligheden er afslutningen på det langdigt bogen udgør) er den almindelige norske skjære i digtets første halvdel et (sind)billede på erindringen om broren, brorerns konstante nærvær så at sige ("jeg får det ikke med meg, krakser han / jeg får det ikke til å gå opp, knyr han / jeg skjønner ikke hva du vil engang, skratter han / og kvider litt selvfornøyd at det gjorde han forresten aldri"); i det efterliv han lever i jegets bevidsthed, ligner han ikke længere sig selv, står der, og han får knyttet en række skjære-attributter på sig; stemmen, udseendet, han bliver den fugl der så symbolsk letter og endelig lader jeget i fred. Ja, min læsning er måske banal og selvindlysende, men vi er jo enige om at prøve os med enkelte nærlæsninger. I digtets anden halvdel taler jeget til den fraværende bror ("nå er det jo uansett for seint, sier jeg / men broren min hører ikke på meg"). Dengang broren var i live, forstod han ikke alt hvad jeget sagde, men "reiste seg ikke før jeg hadde snakket ferdig / uansett hvor lang tid jeg brukte". Akkurat som fuglen i digtet. Men nej, siger jeget, nej, det er jo fjollet at lade som om at ens døde bror vender tilbage som fugl eller i det hele taget at fortidens spøgelser skulle manifestere sig konkret fysisk: "jeg tror jo ikke på at de som dør skal dukke opp igjen / som røyk eller flate fargeløse bilder i lufta, som trær eller fugler eller / dører som blir åpnet og lukket og knirking i gulv - men kanskje som knirking i måter / å tenke på seg selv på," - alligevel slutter digtet og bogen med disse ord: "og da jeg ser ut av vinduet har broren min for lengst blitt borte / han har løftet de svarte sjaskete vingene sine og flydd". Fuglen bliver mere end en fugl, udover konkret at repræsentere den andens, brorens, nærvær, bliver den også en art fordobling af læseren i digtet, vidnet, den der bevidner jegets tale - og nu da jeget ikke har mere at sige, nu da han så at sige er nået frem, kan fuglen lette og flyve sin vej. Tilbage til naturen, som Per Højholt har skrevet i et digt om solsortens hyppige gæsteoptræden i poesien ("En solsort kom flyvende / inde fra tågen // den sidder her nu / og synger i en våd bjergfyr // om lidt flyver den tilbage / til naturen"). Min pointe med denne minilæsning, der jo virkelig er en meget traditionel nærlæsning der næsten udelukkende bevæger sig på indholdsplanet og altså ikke gør noget af alt det du efterlyser (men du kunne måske give dit eget bud, læse præcis samme digt?!), er den at uanset hvor meget du tilsyneladende sværger til det konkrete (som du jo selv aktivt undergraver), indskrives der i den poesi du skriver en merværdi, en valorisering, symbolsk, metaforisk, metonymisk, hvad det nu alt sammen hedder, men det er vel det der kaldes at digte? Det er en underlig modstand du har imod denne type læsninger, synes jeg; som om indholdet ikke var fint nok, men kun formen, som om indholdet ikke eksisterede... Ja, jeg fortegner dig lidt, gør dig til en stråmand. Jeg ville ønske jeg ikke opererede med denne type dikotomier - formindhold - jeg tror ikke på dem, men det er vanskeligt at tale om ellers, uden, ikke mindst fordi det for mig ser ud som om du kvier dig ved at tale om hvad den poesi der bliver skrevet nu mon kunne betyde eller tyde på, har den overhovedet noget tilfælles, synes du, den unge norske poesi, eller er den der bare, sig selv, fuldkommen upåvirket af hvor og hvornår, af hvem og hvordan den er skrevet?

Et sidste pip med hensyn til fuglens symbolske betydning i dit digt: Måske er den der bare, der er mange fugle i mange digte, de sidder her lidt før de flyver til- 
bage til naturen igen. (Jeg har selv forsøgt mig med en fugle-afmontering som din $i$ et af mine digte, citatet er fra langdigtet 4 (2005): "fuglen udenfor vinduet den har siddet der i en halv time nu er det mig den glor på? / den har en gigantisk gren i næbbet måske det er derfor den ikke flyver sin vej / den kan ikke bære grenen og vil ikke give slip / også dét tænker jeg kunne betyde noget / men det gør det ikke det er en fugl ikke andet jeg ved ikke engang hvilken slags / den er brun i det".

Jeg ville gerne skrive mere om nogle af de tanker jeg har haft med at implementerer Georg Johannesens (og andres) citat(er) i Trafikken er uvirkelig (2007), jeg ville gerne skrive lidt om hvordan det deklamatoriske og autoritative, som jeg mener man kan finde hos Wærness og Opstad fx, ikke findes i dine bøger i samme grad; de er fulde af tvivl, usikkerhed og selvrettelser (og skulle det ikke være en forskel?), jeg ville gerne skrive om digte hos digtere som Lyn Hejinian, Gertrude Stein, Caroline Bergvall - og Eldrid Lunden i det første stykke du citerer ovenfor om hvordan jeg ikke umiddelbart synes jeg finder "pausernes bulder" hos dem, jeg ville gerne spørge dig om på hvilken måde du synes det ville være adekvat at gribe det an, hvis vi skal sige noget om norsk litteratur, mere præcist måske norsk poesi, lige nu, men det bliver for langt, jeg er for træt. Klokken er 05:58, hele natten er gået, udenfor er det lyst igen, lyseblåt og blæsende, børnene vågner senest om en time. Jeg må i seng. Jeg glæder mig til at høre fra dig. Ikke mindst kunne jeg tænke mig at vide hvad der skete med de fugle, med den bande skjærer der hærgede dit kvarter, hvordan I blev af med dem igen, forsvandt de af sig selv?

på kjøkkenet hjemme, Oslo, tirsdag 19. august (jeg har en fiskegryte på komfyren og snart kommer de andre hjem)

Kjære Martin,

Skjærene er her fortsatt, men den mest aggressive av dem forsvant. Den døde antakelig av ergrelse. En annen og litt yngre skjære ble tatt av naboens katt. Men naboens katt har også forsvunnet. Den katta savner jeg, Martin, den pleide å møte ungene ved enden av gata når de kom hjem fra skolen og følge dem hjem til porten. Grunnen til at skjæra kom inn i diktet var enkel: jeg sto ved vinduet og tenkte på broren min, så fikk jeg øye på skjæra som satt i treet utenfor. Den satt og betraktet meg, syntes jeg, slik du syntes fuglen i diktet ditt betraktet deg. Dermed satte jeg meg ned og skrev disse to tingene sammen: det jeg hadde tenkt og det jeg hadde sett. Det var ikke mer enn det. Alt jeg la inn i disse skjærene i det forrige brevet kom opp da, i brevet, og bare da, bare der. Men se på meg nå, Martin: jeg reiser meg opp og går til vinduet, på taket til naboen sitter som vanlig en av disse skjærene og vipper med stjerten. Denne skjæra er spinkel og ser litt nervøs ut, og jeg tenker at skjærer er lettskremte vesener som altfor lett kommer ut av balanse. Verden er ikke stabil, og det er ikke blikkene som ser på den, heller.

Højholts solsort er ikke til å komme utenom, det er jeg enig i. Mye av det Højholt skrev, gjorde visse former for identifikasjon umulig - for den som tar Højholts tekster til seg. (Han var ikke alene om dette, selvfølgelig, men Højholt er god som metafor for noe av det viktigste som skjedde i den skandinaviske poesien på 1960-tallet). 
For min del tror jeg faktisk at det å ha lest Højholt i mange år gjorde det umulig for meg å nærme meg slike motiver som $\mathrm{f}$ eks fugler. Men egentlig tror jeg ikke på den typen bildeforbud. For noen år siden kom det et annet tonefall inn i skrivingen min, der jeg syntes det ble mulig for meg å skrive inn fugler og trær og regn og snø og vind og nesten hva som helst annet av det som tilsynelatende er natur - ikke som besjeling i naiv forstand, men som et slags dobbeltspråk, et språk som prøver å gå inn og ut av ulike strategier.

(Gir det mening å si det sånn?) (Jeg er jammen ikke sikker.) (Jeg lar det stå likevel.)

Jeg var ute i går, alt for lenge ute, sto opp alt for seint og fant mailen din fra $\mathrm{i}$ natt, skrev den ut og leste den på bussen til byen. Og da jeg gikk over St. Olavs plass og snakket med deg, eller med det du hadde skrevet til meg, rygget en enorm hvit lastebil ut fra en av sidegatene, rett foran ansiktet på meg. Like bak førerhuset hadde lastebilen et skilt med denne teksten: DU STÅR NÅ I MIN BLINDSONE. Kjører du bil, Martin? Det som befinner seg i blindsonen er det du ikke får øye på verken i bakspeilet eller sidespeilet. Du må snu deg rundt, kanskje bøye deg langt over til siden (mens du fortsatt holder i rattet) om du skal få øye på det. Jeg har egentlig aldri skjønt metaforen om den "blinde flekken" - den som så mange litterater er så glade i - men her kom hele metaforen ryggende rett inn foran ansiktet på meg, og var altså ikke til å unngå.

Det er mulig at du beveger deg i blindsonen min, Martin, at jeg ikke har anstrengt meg nok med å forstå - det er mulig jeg burde snu meg rundt og bøye meg litt lenger over til siden. Men likevel prøver jeg en gang til, som om jeg ikke var i stand til noe annet enn å pukke på mitt eget. Hør på meg nå: har ikke du også skrevet diktanalyser der du måtte skille pliktskyldig mellom motiv og tema? Et dikt om et tre som seint på høsten står ribbet for blader, for eksempel, i blåsten, eller blesten, det diktet får ikke lov til å handle om et tre som seint på høsten står ribbet for blader, det må handle om noe annet, noe mer, noe dypere og mer seriøst. Altså om døden. Treet om høsten er diktets motiv, men døden er diktets tema, var det ikke sånn? Men jeg tror ikke denne måten å lese på gir så mye mening, ikke i forhold til de diktene jeg leser, eller prøver å skrive. Og likevel klarer jeg ikke å la det være, kjære du, tilgi meg dette, men jeg lurer altså på om ikke det religiøse språket du finner i noen av de diktene du skriver om, hører til diktenes motiv, rester av et språk som plukkes opp og blir brukt til noe annet. Disse diktene handler ikke om tro eller religion, de benytter seg blant mange andre ting av restene etter et religiøst språk. Og hva bruker de det til? Jeg for min del merker at den måten diktene til Gunnar Wærness synger på, gjør noe med meg, åpner meg opp, gjør meg lettere og svakere og mer sårbar. Og jeg mener virkelig at man kommer nærmere det disse diktene arbeider med ved å se på måten de synger på.

De diktene jeg helst leser har noe ved seg som minner om det Roland Barthes har kalt avlyssnat språk (jeg leste Barthes på svensk og klarer aldri å si det på noen annen måte): det er som om språket lytter på seg selv mens det skrives frem, som om selve meningen utfolder seg i en biklang, en liten dirring mellom ordene. Det er ikke så viktig for meg hva som står i et dikt hvis det bare beveger seg, for å si det litt dumt. I din diktbok Trafiken er uvirkelig skrives det også frem en stemme som er 
lyttende, linjene kommer som om de er sitater, hvilket noen av dem er, men selvfølgelig langt fra alle. Det er noe prøvende og utspørrende over tonen, som er langt viktigere enn de faktiske påstandene som din bok er full av.

Eller tenk på Øyvind Bergs dikt "Samla", som oppsummerer verden på fem linjer: "idéen bak Gud var å samle seg, ikke sant / like forbanna ble det full spredning / for vi sto skrevet i nerver, ikke sant / mot noe som kan være himmelen / kan være lyset i himmelen, ikke sant".

Diktet kommer frem som en replikk, det er en sitataktig skjevhet i det, i måten "ikke sant" blir gjentatt på, som om noe av det viktigste for dette diktet var å høre på seg selv, spørrende og like fullt ganske pågående i sin måte å bygge opp og plukke fra hverandre all verdens mening på. Hva er dette diktets motiv og tema? Hva er det diktet jobber med? Mest av alt jobber det frem en stemme, en måte å snakke på, som jeg tar til meg direkte, som gjør at jeg tenker litt i samme melodi, i samme slags rytme som dette ble skrevet i, ofte. Det er en slags omvendt salme det diktet, synes jeg, og der satt jeg vel med den ene foten i den religiøse saksa di, tenker jeg. Jeg vil bare si at du har rett, selvfølgelig har du rett, Martin, men i hva?

på rommet til Peter, onsdag 20. august

Sønnen min er ikke hjemme og jeg satte meg på rommet hans for å være i et annet rom, men jeg kan ikke sitte og skrive så lenge nå, jeg må snart gå ut igjen fordi jeg glemte å sende med den yngste datteren min gummistøvler i barnehagen, det velter ned ute, et avmektig regn som bare plasker ned, like kraftløst og undergravende som den liberalistiske vendingen i norsk $\varnothing$ konomi, og da nytter det ikke for en treåring å leke ute med sko på beina. Men du, jeg er ikke er enig med deg i at det er mulig å gå glipp av noe som helst ved å lese på nært hold, jeg tror det er omvendt, som sagt, at meningen er en avgrunn som åpner seg i diktenes enkelte ledd. Og det kan jeg vanskelig tro du er uenig i heller, så vi lar den ballen ligge.

(Ballen? Ligge?) (Du var overrasket over min heftighet i det første brevet, men du bor ikke i Norge, Martin, du trenger ikke lese disse kulturkommentarene som oppsummerer tendenser hver gang de åpner øynene, som om det viktigste i verden eller litteraturen var hva slags tendenser den gir uttrykk for. Dette er jo nesten alltid en måte å ikke lese på, en måte å se vekk fra alt som ikke passer inn, en måte å gi seg selv rett på, uansett hva man forholder seg til. Alt det som avviker, alt det som motarbeider forenkling og oppsummering, alt det som synger og vrir seg i et dikt er noe annet enn forretningsideer.) (Norge, Martin, ikke den norske litteraturen men den norske litteraturinstitusjonen, er litt sånn: ikke diskusjon men debatt, ikke fordypning men oppsummering, ikke motstand men forretningsideer.)

Hvor fører dette hen? Hvis vi senere en gang skal snakke videre om hva og hvordan noe i diktet kan oppsummeres i en annen form, vil jeg foreslå at vi tar opp C.J.L. Almquists skrift fra 1844-45 "Om poesi i sak", eller Gunnar Ekelöfs artikler om Almquist, eller Jan Erik Volds artikler fra 1960-tallet om poesi i sak og om Ekelöf. Men det får vente!

For det slutter, som vanlig, med døden. Det finnes nemlig en usedvanlig vakker beskrivelse av Gunnar Ekelöfs siste handling, beskrevet av Ingrid Ekelöf, i boken En 
självbiografi (1971). Boken kom ut igjen på nytt i fjor, i pocket, og du finner scenen jeg snakker om på side 300. Denne scenen har Jan Erik Vold brukt som underlag for et av sine dikt, med tittelen "Ekelöfs hjerte" (fra diktsamlingen Sorgen. Sangen. Veien, fra 1987). Diktet går sånn: "Ekelöfs / siste / akt: Han kneppet opp pyjamas // jakka, famlet med fingrene / oppover / venstre / sides // ribbein, pekte // og / sa: Här. / Här är det."

Ja? Hjertet er en feit metafor, og man skulle forsverge at det lot seg gjøre å skrive et sånt dikt, men jeg synes det gikk ganske bra, synes ikke du også? Og selve handlingen, Ekelöfs siste akt, er vel nettopp en slags poesi i sak: den kan gjenfortelles på ulike måter, på ulike språk, i ulike sjangre, den brenner seg gjennom som en overvintret melding, den blir gjentatt og virker, den er. Ja, som et dikt.

Vel, Martin. Mine tekster står i et demonstrativt stramt blokkformat og dine med en avslappet ujevn høyremarg, skal vi beholde det sånn, tror du? 